\title{
Antibacterial Activity of Oriental Medicinal Herb Extracts against Skin Pathogens
}

\author{
Young Eun Yu', Eun Young Park', Dae Hwa Jung ${ }^{1}$, Sung Hui Byun², Sang Chan Kim¹,2
} and Sung Min Park ${ }^{1}$.

${ }^{1}$ The Research Center for Biomedical Resources of Oriental Medicine, ${ }^{2}$ College of Oriental Medicine, Daegu Haany University, Daegu, 706-828, Korea

Received May 17, 2010 /Accepted June 17, 2010

\begin{abstract}
The antibacterial activity of methanol extracts from 70 kinds of oriental medicinal herbs on four strains of Staphylococcus aureus and S. epidermidis was investigated. The results showed that $C$. japonica, $C$. sappan, $R$. javanica, $R$. tanguticum, and $S$. miltiorrhiza had an antibacterial activity on all the strains used. Among these, $C$. japonica and $R$. javanica, which showed excellent antibacterial activity, were extracted with water, ethanol, methanol, and ethyl acetate for further study of antibacterial activities. The results showed that the boiled water extract of $C$. japonica had the best antibacterial activity. Assuming that the antibacterial activity of $C$. japonica originated from berberine, which has been reported many times, the berberine content of the boiled water extract of $C$. japonica was analyzed and the result was $13.88 \%$. To compare the antibacterial activity of berberine with that of other antibiotics, berberine chloride and three other kinds of antibiotics were investigated, which showed that berberine chloride had an antibacterial activity on KCCM 35494 S. epidermidis only when the concentration was higher than $600 \mathrm{mg} / \mathrm{l}$, and it did not show antibacterial activity in the other strains. Based on these results, it was concluded that the antibacterial activity of the boiled water extract of $C$. japonica on the strains used in this study originated from high concentration of berberine or substances other than berberine. Therefore, identification of the substance will be necessary.
\end{abstract}

Key words : Skin pathogen, oriental medicinal herb, antibacterial activity

\section{서 론}

산업화를 통한 생활양상의 변화는 다양한 분야에서 사람들 의 생활을 보다 윤택하고 편리하게 지낼 수 있는 여건들을 제공하였으며 특히 질병을 예방하고 치료할 수 있는 다양한 항생제의 개발은 사람들이 질병의 두려움에서 벗어나 보다 건강한 생활을 할 수 있는 기회를 제공해 주었다. 항생제의 개발은 현대 의학이 이룩한 가장 위대한 업적 중 하나로서 페니실린이 도입된 1940년 이후 수많은 감염질환의 완치가 가능하여 졌으나 불과 60여 년 만에 항생제 내성의 광범위한 출현은 각종 감염질환의 치료 실패와 치명적인 결과를 야기하 고 있다[22]. 항생제에 대한 내성을 극복하고 질병의 치료를 위하여 다양한 소재를 이용한 연구가 진행되고 있으나 기존의 항생제와 비교할 때 효과가 적어 아직까지 실용화되어 산업화 된 경우는 매우 미비하다. 그러나 전 세계적으로 다양하게 존 재하는 천연물의 생리활성 성분을 이용한 연구가 활발하게 진행되고 있으며 이러한 연구의 결과를 바탕으로 우수한 새로 운 항생제의 산업화가 가능할 것으로 예상된다 $[1,5-7,14,20]$.

우리나라에서도 천연물의 생리활성 성분을 이용한 다양한 분야에 대한 연구가 진행되고 있으며 특히 질병에 대한 약물

*Corresponding author Tel : +82-53-770-2332, Fax : +82-53-770-2335

E-mail : minshell@dhu.ac.kr
의 개발에 많은 연구가 이루어지고 있다[2,8-11,19]. 그리고 약 물의 개발뿐 아니라 화장품소재, 식품첨가물과 염료 등 일상 생활에서 많이 사용되는 합성물질과 사료 중 항생제를 대체할 수 있는 물질의 개발에도 많은 연구가 진행 중이다 $[3,4,6$, $12,23,24]$. 천연물 중 한약재를 이용한 연구가 가장 활발하게 진행되고 있으며 한약재의 생리활성 성분을 이용한 다양한 제품은 일상생활에서 쉽게 찾아볼 수 있게 되었다[9,16-18,24].

본 연구자들도 한약재를 이용한 다양한 연구분야 중에서 피부 질환과 관련된 연구를 진행하고 있으며 특히 염증과 관 련된 연구를 진행하고 있다. 일반적으로 피부 상재균 중 피부 에 염증을 유발할 수 있는 세균으로는 Staphylococcus epidermidis, S. aureus, Streptococcus pyogenes 등이 보고되어 있으 며, 특히 피부 여드름 유발 원인세균으로는 Propionibacterium acnes가 알려져 있다. 여드름의 약물치료는 피지 과잉생산 억 제, 모낭벽의 과각화 방지, P. acnes의 증식억제 및 염증반응의 방지 측면에서 개발되고 있으며, 현재는 여드름이 있는 부위 에 직접 발라주는 국소 요법제와 내복약을 통한 전신 요법이 사용되고 있다. 그러나, 현재 사용되고 있는 erythromycin, isotretinoin, benzoyl peroxide, vitamin A acid, triclosan 및 azelaic acid 등의 약물은 많은 부작용과 내성균주의 출현 등의 문제점이 보고되고 있다[10,21]. 
이러한 문제점을 해결하기 위하여 한방 생약기술 및 다양한 약용 한방자원의 사용을 바탕으로 천연물 유래의 예방, 완화 및 치료제 개발이 활발하게 진행되고 있다[21].

따라서, 본 연구에서는 한약재를 사용하여 피부 염증에 관 여하는 Staphylococcus epidermidis와 S. aureus를 대상으로 항균 활성을 조사하고 그 결과를 보고하고자 한다.

\section{재료 및 방법}

\section{실험 재료}

피부 염증 유발 세균에 대한 한약재의 항균성을 조사하기 위하여 한의학 중 본초학을 바탕으로 문헌 조사를 진행하여 한약재를 선발하였다. 한약재의 구입은 대구시 수성구 상동 소재 대원약업사에서 생약제제로 포장되어 판매하는 제품을
사용하였으며 조사를 위한 추출물을 제조할 때 마다 구입하여 사용하였다(Table 1).

\section{메탄올 추출물의 제조}

선발한 한약재 중 피부 염증 유발 세균에 대한 항균성을 나타내는 한약재를 선별하기 위하여 우선 메탄올 추출물을 제조하여 조사하였다.

각각의 한약재에 10 배 량의 메탄올을 첨가하고 실온에서 3 일간 정치하여 추출한 후 각각의 추출액을 여과(Filter paper No. 2, Whatman, Japan)하였다. 회수한 메탄올 추출액은 소형 회전농축기(Rotary evaporator, Eyela, Japan)로 농축하고 솔 벤트 농축기(High throughput centrifugal evaporator, Genevac, UK)를 이용하여 잔존 용매를 제거한 다음 추출물을 준비하였다.

Table 1. List of oriental medicinal herbs for this study

\begin{tabular}{|c|c|}
\hline Species Name (Part, recovery rate) & Species Name (Part, recovery rate) \\
\hline Areca catechu (Seed, 7) & Lithospermum erythrorhizon (Root, 33) \\
\hline Artemisia apiacea (Aerial part, 9) & Lonicera japonica (Flower, 45) \\
\hline Artemisia capillaris (Aerial part, 12) & Lycium chinense (Fruit, 24) \\
\hline Artemisia princeps (Leaf, Stem, 11) & Lycopus coreanus (Aerial part, 14) \\
\hline Caesalpina sappan (Stem, 8) & Melia azedarach (Fruit, 21) \\
\hline Capsicum annuum (Fruit, green, 46) & Mentha arvensis (Aerial part, 21) \\
\hline Capsicum annuum (Fruit, red, 59) & Morus alba (Fruit, 64) \\
\hline Carthamus tinctorius (Flower, 6) & Nelumbo nucifera (Leaf, 12) \\
\hline Chaenomeles sinensis (Fruit, 85) & Oldenlandia diffusa (Leaf, 7) \\
\hline Chelidonium majus (Aerial part, 11) & Paeonia suffruticosa (Root, 22) \\
\hline Chrysanthemum indicum (Flower, 49) & Perilla frutescens (Leaf, Stem, 21) \\
\hline Cinnamomum cassia (Stem, 6) & Persicaria tinctoria (Leaf, 2) \\
\hline Cirsium japonicum (All, 13) & Phaseolus angularis (Seed, 0) \\
\hline Citrus unshiu (Fruit, 64) & Phaseolus radiatus (Seed, 0) \\
\hline Citrus unshiu pericarpium (Fruit, 35) & Phellodendron amurense (Bark, 26) \\
\hline Clematis mandshurica (Root, 18) & Polygonum aviculare (All, 10) \\
\hline Cnidium monieri (Fruit, 7) & Poncirus trifoliata (Fruit, 32) \\
\hline Commelina communis (Aerial part, 6) & Prunus mume (Fruit, 73) \\
\hline Coptis japonica (Root, 12) & Rheum tanguticum (Root, 89) \\
\hline Cornus officinalis (Fruit, 123) & Rubus coreanus (Fruit, 8) \\
\hline Corydalis ternata (Stem, 2) & Ruhus javanica (Cocoon, 21) \\
\hline Crataegus pinnatifida (Fruit, 129) & Salvia miltiorrhiza (Root, 15) \\
\hline Curcuma longa radix (Root, 29) & Santalum album (Stem, 9) \\
\hline Curcuma longa Rhizoma (Root, 14) & Sasa japonica (Leaf, 11) \\
\hline Curcuma zedoaria (Root, 7) & Saururus chinensis (Aerial part, 38) \\
\hline Dianthus chinensis (Aerial part, 21) & Schisandra chinensis (Fruit, 99) \\
\hline Eclipta prostrata (All, 21) & Schizonepeta tenuifolia (Flower, 5) \\
\hline Elsholtzia ciliata (All, 15) & Scrophularia buergeriana (Root, 22) \\
\hline Foeniculum vulgare (Fruit, 7) & Scutellaria baicalensis (Root, 25) \\
\hline Forsythia viridissima (Fruit, 31) & Sophora japonica (Flower, 24) \\
\hline Gardenia jasminoides (Fruit, 44) & Spatholobus suberectus (Stem, 16) \\
\hline Gentiana scabra (Root, 52) & Spirodela polyrhiza (Leaf, 16) \\
\hline Isatis tinctoria (Root, 27) & Taraxacum platycarpum (All, 18) \\
\hline Leonurus sibiricus (Aerial part, 9) & Thuja orientalis (Branch, 35) \\
\hline Ligustrum lucidum (Fruit, 26) & Xanthium strumarium (Fruit, 5) \\
\hline
\end{tabular}


회수율은 회수된 추출물의 중량을 회수에 사용한 한약재의 중량으로 나눈 후 백분율로 계산하였다.

\section{용매별 추출물의 제조}

선발한 한약재의 메탄올 추출물을 이용하여 피부 염증 유발 세균에 대한 항균성 조사의 결과를 바탕으로 양호한 항균성을 나타내는 한약재를 선별하고 물, 에탄올, 메탄올과 에틸아세 테이트를 추출 용매로 하여 추출물을 제조하였다.

에탄올과 에틸아세테이트 추출물의 경우 앞서 준비한 메탄 올 추출물과 동일한 방법을 이용하여 준비하였다. 물 추출물의 경우 10 배 량의 3 차 정제수를 가하여 $85^{\circ} \mathrm{C}$ 에서 2 시간 정도 중탕 하고 대형회전농축기(Rotary evaporator, Buchi, Switzerland) 로 감압 농축한 후 동결건조(Freeze dryer, Eleya, Japan)하여 회수한 분말을 사용하였다.

\section{공시균주}

Table 2의 세균을 공시균주로 사용하였으며 한국미생물보존센 터(KCCM, Korean Culture Center of Microorganisms)와 항생제 내성균주은행(CCARM, Culture Collection of Antimicrobial Resistant Microbes)에서 각각 분양 받아 사용하였다.

공시균의 배양을 위하여 KCCM 35494 Staphylococcus epidermidis는 Nutrient medium $(0.3 \%$ beef extract, $0.5 \%$ peptone, $\mathrm{pH}$ 6.8, Becton, Dickinson and Company, USA)를 사용 하였으며 CCARM 3708 S. aureus, CCARM 3709 S. epidermidis, CCARM 3710 S. epidermidis와 CCARM 3711 S. epidermidis 는 Brain heart infusion medium $(0.77 \%$ calf brains, $0.98 \%$ beef heart, $1.0 \%$ dextrose, $0.5 \%$ sodium chloride, $0.25 \%$ disodium phosphate, $\mathrm{pH}$ 7.4, Becton, Dickinson and Company, USA)를 사용하였다.

공시균은 $37^{\circ} \mathrm{C}$ 에서 배양하여 사용하였으며 $4^{\circ} \mathrm{C}$ 에서 보관 하여 주에 한 번씩 계대 배양하고 실험 2일전 다시 계대 배양 하여 균을 활성화 시킨 후 사용하였다.

\section{항균성 조사}

한약재 추출물의 항균성을 조사하기 위하여 실험 하루 전 공시균을 접종하여 $37^{\circ} \mathrm{C}, 24$ 시간 배양하고 $7,805 \times g$ 에서 2 분간 원심분리 하여 균체를 회수한 후 상등액을 제거하고 멸균수를 첨가하여 현탁 하였으며 잔존 배지성분과 공시균의 생육과정

Table 2. Antibacterial activity investigated strains in this study

\begin{tabular}{lll}
\hline Strain No. & Strain name & Sources \\
\hline CCARM 3708 & Staphylococcus aureus & Clinical isolated \\
CCARM 3709 & Staphylococcus epidermidis & Clinical isolated \\
CCARM 3710 & Staphylococcus epidermidis & Clinical isolated \\
CCARM 3711 & Staphylococcus epidermidis & Clinical isolated \\
KCCM 35494 & Staphylococcus epidermidis & Clinical isolated \\
\hline
\end{tabular}

에서 세포 외로 방출되는 물질 등을 제거하고자 3 번 반복하여 준비하였으며 $1.5 \pm 0.5 \times 10^{8}$ cells $/ \mathrm{ml}$ 로 균수를 조정하여 사용 하였다.

선발한 한약재의 항균성을 조사하기 위하여 메탄올 추출물 을 이용한 선행조사를 수행하였으며 이 결과를 바탕으로 양호 한 항균성을 나타내는 한약재를 선별하고, 선별한 한약재를 열수, 에탄올, 메탄올과 에틸아세테이트 추출물을 제조하여 조사하였다.

추출물은 추출 시 사용한 용매를 이용하여 $\mathrm{g} / \mathrm{ml}$ 의 농도로

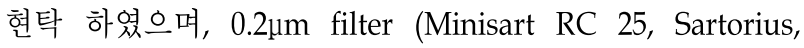
Germany)를 사용하여 제균하여 사용하였다.

항균성은 한천평판확산법(Agar diffusion method)을 이용 하여 조사하였으며 지름 $6 \mathrm{~mm}$ paper disc (Advantec, Japan) 에 각각의 추출물 $20 \mu \mathrm{l}$ 를 점적한 후 무균상태에서 충분히 건 조하여 추출용매에 의한 공시균주의 생육저해 가능성을 차단 한 후 배양하여 조사하였다. 추출물이 나타내는 항균성 여부 는 공시균의 생육이 억제되면서 형성되는 생육저지환(Clear zone)의 크기로 확인하였으며 가장 우수한 항균성을 나타내는 한약재를 최종 선별하였다.

또한 Purifier ${ }^{\circledR}$ Biological Safety Cabinet (Labconco ${ }^{\circledR}$, USA) 를 사용하여 공시균의 접종 등의 과정을 수행하였다.

\section{선별 한약재의 항균성 물질 확인}

항균성이 가장 우수한 것으로 조사된 한약재가 함유하고 있는 물질의 분석은 UPLC (Ultra high performance liquid chromatography, Waters, USA)를 이용하였으며 사용 용매는 모두 특급을 사용하였다. 증류수는 탈이온 처리하였으며 사용 전 $0.2 \mu \mathrm{m}$ filter (Minisart RC 25, Sartorius, Germany)로 여과 하여 사용하였다. 물질의 확인은 표준품으로 농도구간을 설정 하고 그 결과를 이용하여 검량선을 작성한 후 조사하였다 (Table 3).

\section{항생제와의 항균성 비교}

가장 우수한 항균성을 나타내는 한약재의 추출물과 CCARM 균주가 감수성을 가진다고 보고된 항생제 중 clindamycin hydrochloride (Sigma, USA), erythromycin (Sigma, USA)과 tetracycline (Sigma, USA)를 이용하여 항균성을 비교하였다.

Table 3. Operation conditions for UPLC analysis

\begin{tabular}{ll}
\hline Parameter & Conditions \\
\hline Column & $\begin{array}{l}\text { ACQUITY UPLC }{ }^{\circledR} \text { BEN C18 Column } \\
(2.1 \times 100 \mathrm{~mm})\end{array}$ \\
Solvent system & $\begin{array}{l}0.1 \% \text { formic acid in } 100 \% \text { ACN }, 0.1 \% \\
\text { formic acid in } \mathrm{H}_{2} \mathrm{O}\end{array}$ \\
Flow rate & $0.4 \mathrm{ml} / \mathrm{min}$ \\
Detector & PDA $345 \mathrm{~nm}$ \\
Injector volume & $2 \mu \mathrm{l}$ \\
\hline
\end{tabular}




\section{결과 및 고찰}

\section{메탄올 추출물의 회수율 및 항균성}

선발한 한약재의 메탄올 추출물의 회수율은 Table 1 과 같이 조사되었다. 70 종의 한약재 중 산수유와 산사의 경우 $120 \%$ 이상의 회수율을 나타내었고 고추 외 7종의 경우 $50 \%$ 이상의 회수율을 그리고 빈랑자 외 57 종은 $50 \%$ 미만의 회수율을 나타 내었다. 특히 적소두와 녹두의 경우에는 $0 \%$ 로 조사되었으며 이는 회수율의 산정 시 소수점의 한 자리에서 반올림한 본 연구자의 계산법을 적용하지 않더라도 메탄올에 의하여 한약 재의 성분 추출은 거의 일어나지 않았다.

전배양액으로부터 회수하여 준비한 공시균주 현탁액 100 $\mu 1$ 를 첨가하여 만든 고체배지에 각각의 메탄올 추출물 $20 \mu 1$ 를 점적한 paper disc를 얹고 $37^{\circ} \mathrm{C}$ 에서 24 시간 배양한 후 생육저 지환의 생성 유·무를 관찰하였다. 그 결과 KCCM $35494 S$. epidermidis는 메탄올 추출물 중 황련, 소목, 황백, 오배자, 대황 과 단삼에 의한 생육저지환이 형성되었으며, 이 중 황련(24 $\mathrm{mm})$ 과 오배자 $(22 \mathrm{~mm})$ 추출물에서 가장 우수한 항균성을 나 타내었다. CCARM 3708 S. aureus의 경우 황련, 소목, 오배자, 대황, 황금과 단삼에 의한 생육저지환이 형성되었으며, 황련 추출물에서 $18 \mathrm{~mm}$ 로 가장 우수한 항균성을 나타내었다. CCARM 3709 S. epidermidis는 소목, 황련, 목단피, 황백, 오배 자, 대황, 단삼, 오미자와 측백엽에 의한 생육저지환이 형성되 었으며, 황련 추출물에서 $22 \mathrm{~mm}$ 로 가장 우수한 항균성을 나 타내었다.

CCARM 3710 S. epidermidis는 황련, 소목, 황백, 목단피, 오 배자, 황금, 단삼과 측백엽에 의하여 생육저지환이 형성되었 고, 황련 추출물에서 $24 \mathrm{~mm}$ 로 가장 우수한 항균성을 나타내 었으며 CCARM 3711 S. epidermidis는 메탄올 추출물 중 황련, 소목, 황백, 황금, 오미자, 단삼, 오배자와 대황에 의한 생육저 지환이 형성되었고, 황련 추출물에서 $22 \mathrm{~mm}$ 로 가장 우수한 항균성을 나타내었다. 소목의 경우 성분 중 brazillin에 의한
우수한 항균성을 나타낸다는 권 등[15] 의 보고와 유사한 결과 를 확인할 수 있었으며, 황금의 경우 김 등[13]의 연구결과와 비교할 때 다양한 미생물에 대하여 우수한 항균성을 나타낸다 고 보고되었으나 본 연구에서는 상대적으로 미비한 항균성을 나타내는 것으로 조사되었다. 이는 추출 시 사용한 용매의 차 이 또는 한약재 중 항균성분의 함량 등 다양한 요인에 의한 것으로 판단되었다.

메탄올 추출물 중 한가지 이상의 공시균주에 대하여 항균성 을 나타내는 한약재는 황련, 소목, 황백, 목단피, 오배자, 대황, 황금, 오미자, 단삼과 측백엽으로 조사되었으며 본 연구에서 사용한 공시균주 모두에 대하여 항균성을 나타내는 한약재는 황련, 소목, 오배자, 대황과 단삼으로 전체의 $7.1 \%$ 에 불과하였 다(Table 4).

\section{용매별 추출물의 회수율 및 항균성}

메탄올 추출물을 이용한 항균성 조사에서 모든 공시균주에 대하여 우수한 항균력을 나타내는 것으로 조사된 황련과 오배 자를 선별하여 재료 및 방법과 같이 용매별 추출물을 제조하 였을 때의 회수율은 Table 5 와 같이 조사되었으며 항균력은 Fig. 1과 같았다.

황련은 열수, 에탄올과 메탄올 추출물에서는 항균성을 나타

Table 5. Recovery rate of $C$. japonica and $R$. javanica by different kinds of solvents extract

\begin{tabular}{lcc}
\hline & Solvent & Recovery rate $(\%)$ \\
\hline \multirow{4}{*}{. japonica } & Water & 15.0 \\
& Ethanol & 1.0 \\
& Methanol & 10.0 \\
& Ethyl acetate & 0.1 \\
\hline \multirow{4}{*}{ javanica } & Water & 71.2 \\
& Ethanol & 19.0 \\
& Methanol & 21.0 \\
& Ethyl acetate & 13.0 \\
\hline
\end{tabular}

Table 4. Antibacterial activity of oriental medicinal herbs methanol extract

\begin{tabular}{|c|c|c|c|c|c|}
\hline \multirow{2}{*}{ Species Name } & \multicolumn{5}{|c|}{ Strains } \\
\hline & KCCM 35494 & CCARM 3708 & CCARM 3709 & CCARM 3710 & CCARM 3711 \\
\hline C. japonica & +++ & ++ & +++ & +++ & +++ \\
\hline C. sappan & ++ & ++ & ++ & ++ & ++ \\
\hline$P$. amurense & ++ & - & + & + & + \\
\hline P. suffruticosa & - & - & + & - & - \\
\hline R. javanica & +++ & ++ & ++ & ++ & ++ \\
\hline$R$. tanguticum & + & + & ++ & + & ++ \\
\hline S. baicalensis & - & + & - & + & + \\
\hline S. chinensis & - & - & + & - & + \\
\hline S. miltiorrhiza & ++ & ++ & ++ & + & ++ \\
\hline T. orientalis & - & - & + & + & - \\
\hline
\end{tabular}

* + : $<10 \mathrm{~mm},++:<20 \mathrm{~mm},+++:<30 \mathrm{~mm}$. 


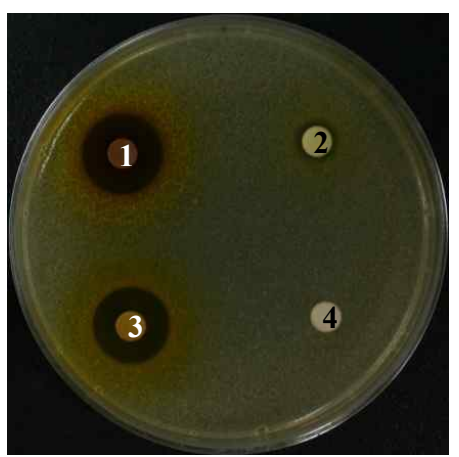

CCARM 3708

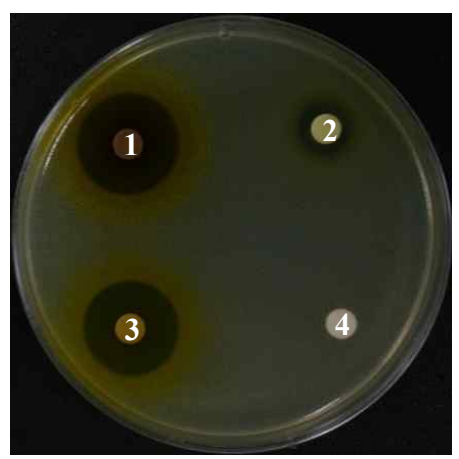

CCARM 3711

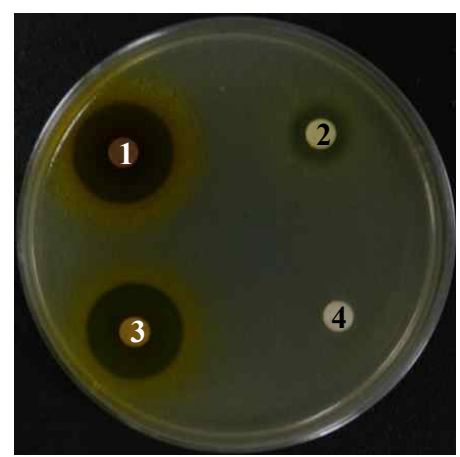

CCARM 3709

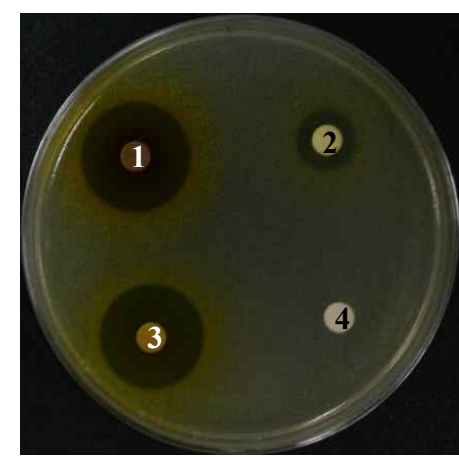

CCARM 3710

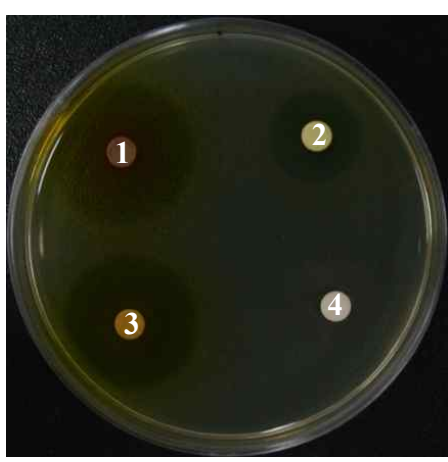

KCCM 35494

(A) C. japonica

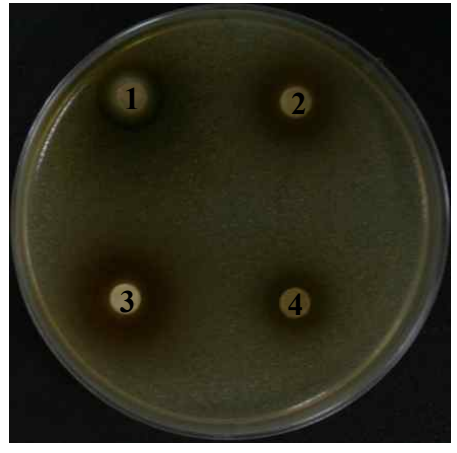

CCARM 3708

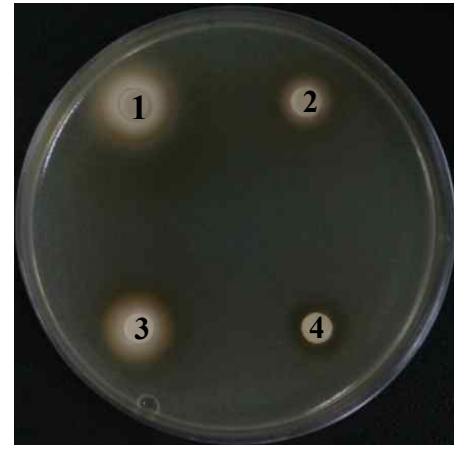

CCARM 3709

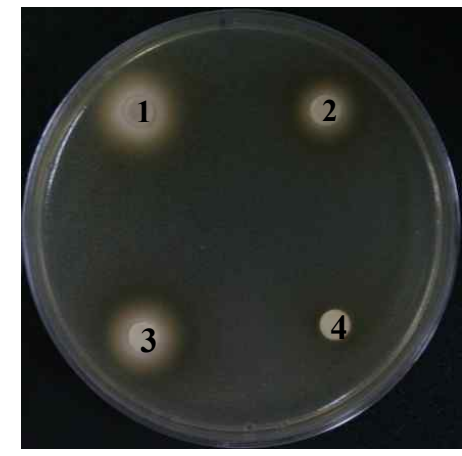

CCARM 3710

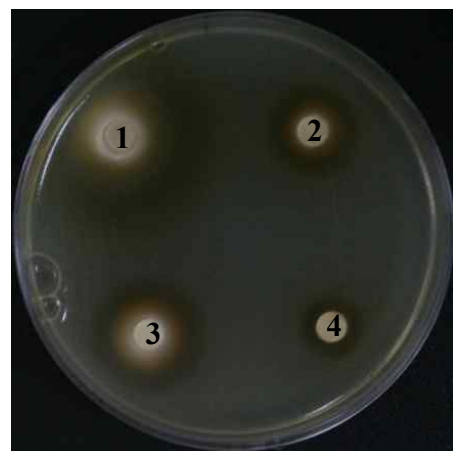

CCARM 3711

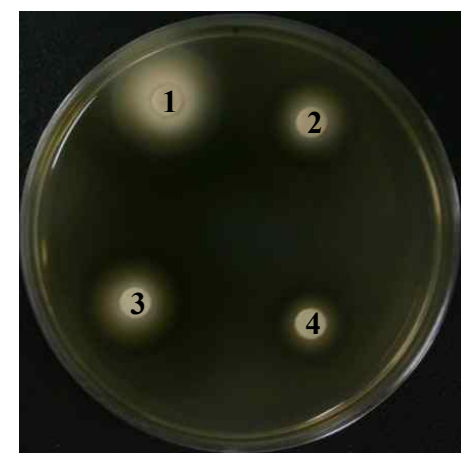

KCCM 35494

(B) R. javanica

Fig. 1. Antibacterial activity of different kinds of solvent extracts on skin pathogenic bacteria. (1) : water extract, (2) : ethanol extract, (3) : methanol extract, (4) : ethyl acetate extract 
내었으나 에틸아세테이트 추출물에서는 항균성을 나타내지 않는 것으로 조사되었으며 열수 추출물이 가장 우수한 항균성 을 나타내는 것으로 조사되었다. 또한 메탄올 추출물도 열수 추출물과 거의 유사한 항균성을 나타내었고 에탄올 추출물의 경우에는 메탄올 추출물의 약 $50 \%$ 수준의 항균성을 나타내는 것으로 조사되었다(Fig. 1A).

황련 열수 추출물의 항균성은 KCCM 35494 S. epidermidis에 대하여 $28 \mathrm{~mm}$ 의 생육저지환을 형성하여 가장 우수한 항균성 을 나타내었으며, CCARM 3708 S. aureus에 대하여 $15 \mathrm{~mm}$ 로 가장 낮은 항균성을 나타내었다.

오배자는 황련과는 달리 에틸아세테이트 추출물에서도 공 시균주에 대한 항균성을 확인할 수 있었다. 추출물 중 열수 추출물에서 가장 우수한 항균성을 나타내었으며 황련의 결과 와 같이 메탄올 추출물도 열수 추출물과 비교할 때 거의 유사 한 수준의 항균성을 나타내었으며 에탄올 추출물의 경우에는 메탄올 추출물의 $70-80 \%$ 수준의 항균성을 나타내는 것으로 조사되었다. 이 결과는 오배자의 메탄올 추출물의 다양한 분 획을 이용하여 가축질병 균주에 대한 우수한 항균성을 확인하 였다는 최[6]의 결과와 유사하였다.

공시균주에 대한 오배자 열수 추출물의 항균성은 $\mathrm{KCCM}$ 35494 S. epidermidis에 대하여 $20 \mathrm{~mm}$ 의 생육저지환을 형성하 여 가장 우수한 항균성을 나타내었으나 CCARM 3708 S. aureus에 대하여 $13 \mathrm{~mm}$ 로 가장 낮은 항균성을 나타내었다.

선별된 한약재의 용매별 추출물의 항균성은 황련 열수 추출 물이 가장 우수한 것으로 조사되었으며 이에 피부 염증 유발 세균에 대한 항균효과가 가장 우수한 한약재로 황련을 최종 선별하였다.

\section{황련의 항균성 물질 확인 및 항생제와의 항균력 비교} 황련의 경우 함유하고 있는 berberine에 의한 항균성이 이 미 많이 보고되어 있으며 이 결과를 이용하여 본 연구자들은 조사 결과가 berberine에 의한 것이라 가정하고 황련 추출물
중 berberine의 함량을 조사한 결과 표준품 $(25,50,100 \mathrm{mg} / \mathrm{l})$ 과 동일한 머무름 시간에서(6분) berberine peak를 확인할 수 있었으며 추출물의 berberine 함량은 $13.88 \%(138.8 \mathrm{mg} / \mathrm{g})$ 로 조사되었다(Fig. 2).

Berberine에 의한 항균성을 확인하기 위하여 berberine chloride (Wako, Japan)를 이용하여 확인하였으며, 비교를 위 하여 CCARM 균주가 감수성을 가진다고 알려진 3종의 항생 제를 사용하여 $100 \mathrm{mg} / 1$ 의 농도로 표준품과 항생제를 준비하 여 한천평판확산법으로 항균성을 조사한 결과 berberine에 의 한 항균성을 확인할 수 없었다. 또한 clindamycin hydrochloride는 CCARM 3710 S. epidermidis에서, erythromycin은 CCARM 3708 S. aureus와 CCARM 3710 S. epidermidis에서, tetracyclin은 CCARM 3711 S. epidermidis와 KCCM 35494 S. epidermidis에 대하여 항균성을 나타내지 않았다.

이에 $100 \mathrm{mg} / \mathrm{l}$ 에서 $1,000 \mathrm{mg} / \mathrm{l}$ 의 농도로 각각 $100 \mathrm{mg} / \mathrm{l}$ 의 농도로 샘플을 준비하여 동일한 방법으로 항균성을 조사한 결과 CCARM 3710 S. epidermidis에 대한 clindamycin hydrochloride와 CCARM 3708 S. aureus 와 CCARM 3710 S. epidermidis에 대한 erythromycine은 $1,000 \mathrm{mg} / \mathrm{l}$ 의 농도에서도 항균성을 나타내지 않는 것으로 조사되었다. Tetracycline의 경우에는 $600 \mathrm{mg} / 1$ 이상의 농도에서 CCARM 3711 S. epidermidis에 대한 항균성은 나타내었으나 생육저지환의 크기가 $<11 \mathrm{~mm}$ 이하로 낮게 조사되었으며 KCCM 35494 S. epidermidis에 대한 항균성은 $1,000 \mathrm{mg} / 1$ 에서도 나타내지 않았다.

Berberine chloride의 경우 $600 \mathrm{mg} / 1$ 이상의 농도에서 KCCM 35494 S. epidermidis에 대한 항균성은 나타내었으나 다른 공시균주에 대한 항균성은 나타나지 않았다. 이에 황련 열수 추출물 중 berberine의 함량을 계산하여 $1,000 \mathrm{mg} / \mathrm{l}$ 이 되도록 조정한 후 berberine chloride와 비교한 결과 Fig. 3에 서와 같이 거의 유사한 것으로 조사되어 황련 열수 추출물의 항균성이 berberine에 의한 것이라 판단할 수 있었다. 그러나 다른 공시균주에 대한 항균성이 확인되지 않는 것으로 미루어

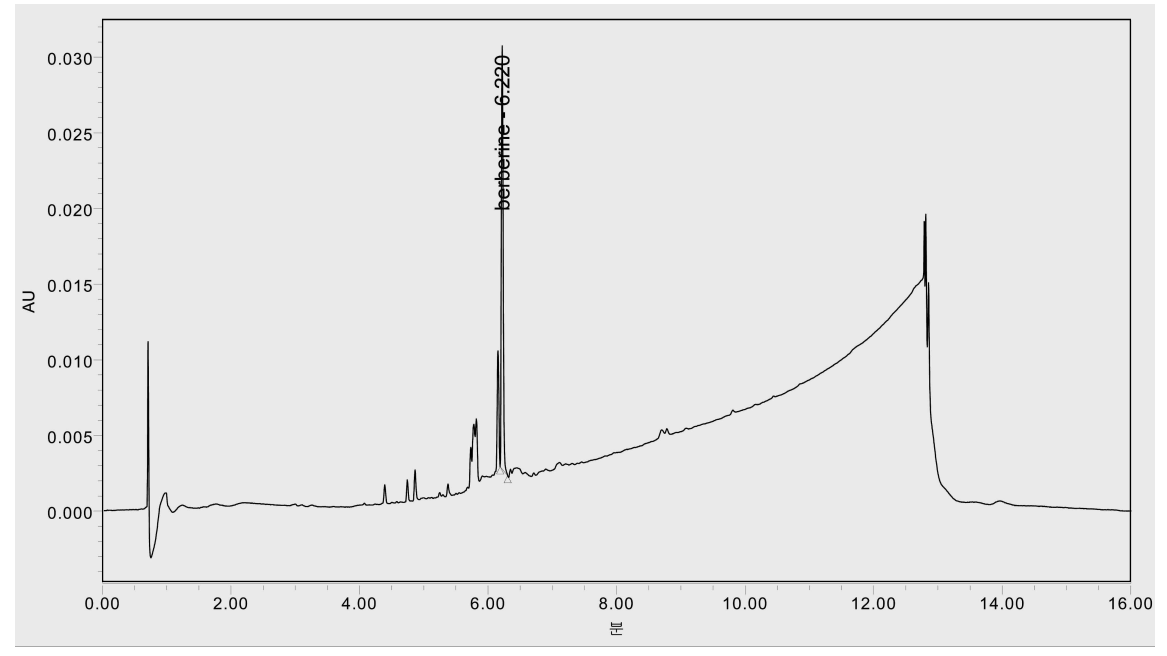

Fig. 2. Chromatogram of water extract of $C$. japonica by UPLC. 


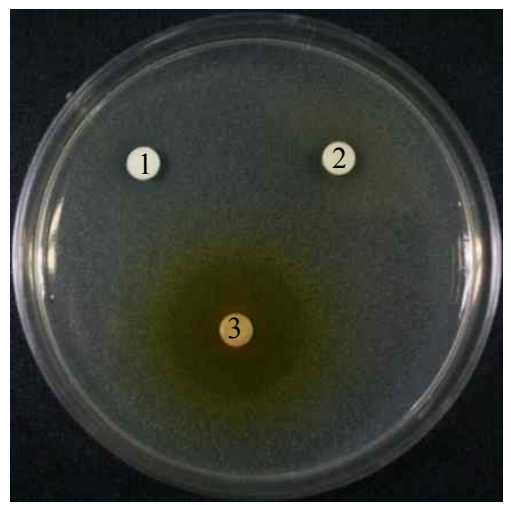

Fig. 3. To compare the antibacterial activity between (1) berberine chloride $(1,000 \mathrm{mg} / \mathrm{l}),(2) C$. japonica $(1,000 \mathrm{mg} / \mathrm{l})$ and (3) $C$. japonica boiled water extract on KCCM $35494 S$. epidermidis.

볼 때 $1,000 \mathrm{mg} / 1$ 이상의 농도에서 항균성을 나타내거나 또는 berbeine 이외 다른 물질에 의하여 항균성을 나타내는 것으로 판단하고 보다 더 연구를 진행하고자 한다.

이 결과는 황련 메탄올 추출물이 열수 추출물보다 항균성이 우수하였으며 berberine chloride를 사용하였을 때 메탄올 추 출물보다 2배 높은 항균성을 나타내었다고 보고한 장 등[8]의 결과와 상이하였으나 사용한 균주의 차이로 인하여 직접적인 비교는 어려운 것으로 판단하였다.

\section{감사의 글}

본 연구는 지식경제부의 지역혁신센터사업(Regional Innovation Center, RIC, B0009008)을 수행하고 있는 대구한의대학 교 한방생명자원연구센터의 지원에 의하여 이루어졌으며 이 에 감사 드립니다.

\section{References}

1. Bakri, I. M. and C. W. I. Douglas. 2005. Inhibitory effect of garlic extract on oral bacteria. Arch Oral. Bid. 50, 645-651.

2. Cho, C. H., G. Y. Yoo, S. Y. Kim, G. S. Lee, J. H. Kim, J. O. H, and H. J. Chae. 2009. Antimicrobial activity and cell cytotoxicity of Korean Plum-yem extract. J. Appl. Biol. Chem 52, 45-50.

3. Choi, H. Y. 2009. Antimicrobial activity of Paeonia japonica extract and its quality characteristic effects in Sulgidduk. Korean J. Food Cookery Sci. 25, 435-444.

4. Choi, H. S., J. S. Kim, D. S. Jang, Y. B. Yu, Y. C. Kim, and J. S. Lee. 2005. Antibacterial activities of Galla rhois extracts against fish pathogenic bacteria. J. Fish Pathol. 18, 239-245.

5. Didry, N, L. Dubreuil, F. Trotin, and M. Pinkas. 1998. Antimicrobial activity of aerial parks of Drosera peltata smith on oral bacteria. J. Ethnopharmacol. 60, 91-96.

6. Choi, I. 2003. Antimicrobial activity of Rhus javanica extracts against animal husbandry disease related bacteria. J. Korean. Soc. Food Sci. Nutri. 32, 1214-1220.

7. Gendron, R., D. Grenier, and L. F. Maheu. 2000. The oral cavity as a reservoir of bacterial pathogens for focal infections. Microbes and Infection 2, 897-906.

8. Jang, G. H., B. Y. Ahn, S. H. Oh, D. S. Choi, and Y. J. Kown. 2000. Anticariogenic effects of Coptis chinensis franch extract. Korean J. Food Sci. Technol. 32, 1396-1402.

9. Kim, J. Y., Y. S. Yi, and Y. H. Lim. 2009. Biological and antifungal activity of herbal plant extracts against Candida species. Kor. J. Microbiol. Biotechnol. 37, 42-48.

10. Kim, J. E., E. H. Kim, and S. N. Park. 2010. Antibacterial activity of Persicaria hydropiper extracts and its application of cosmetic material. Kor. J. Microbiol. Biotechnol. 38, 112-115.

11. Kim, K. D. and S. J. Kim. 2007. Studies on the antimicrobial effect of herbal extracts and it's cosmetic application. J. Kor. Soc. Cosm 13, 221-227.

12. Kim, S. H. 2010. Dyeing properties and the antibacterial activity of Mulberry fiber/cotton blended fabrics with Inonotus obliquus. Journal of the Korean Society of Clothing and Textiles 34, 472-479.

13. Kim, Y. H., J. Y. Peak, H. Y. Kown, J. W. Lee, O. H. Yoon, and M. D. Han. 2009. Antioxidant and antibacterial activities of ethyl acetate extract from Scutellaria baicalensis. Korean J. Food \& Nutr. 22, 367-376.

14. Koru, O, F. Toksoy, C. H. Acikel, Y. M. Tunca, M. Baysallar, A. U. Guclu, E. Akca, A. O. Tuylu, K. Sorkun, M. Tanyuksel, and B. Salih. 2007. In vitro antimicrobial activity of propolis samples from different geographical origins against certain oral pathogens. Anaerobe 13, 140-145.

15. Kwon, H. J., Y. H. Kim, K. W. Nam, S. K. Kim, I. S. Bang, and M. D. Han. 2010. Antibacterial activities of Caesalpinia sappan L. extract and structural analysis of its related Brazilin. Kor. J. Microbiol. Biotechnol. 38, 105-111.

16. Lee, S. K., J. H. Park, and Y. T. Kim. 2009. A study on the antioxidation and antibicrobial effect of Megmoondong (Liriope platyphylla Wang et Tang) water extracts. Korean J. Food \& Nutr. 22, 279-285.

17. Lim, H. A. and S. I. Yun. 2009. Antimicrobial acticities of Capsella bursa-pastoris extracts. Korean J. Food Preserv. 16, 562-566.

18. Park, K. N., E. J. Jeong, and S. H. Lee. 2007. Antimicrobial activity of Turmeric(Curcuma aromatic Salab.) extracts against various pathogens and spoilage bacteria isolated from Tofu. Korean J. Food Preserv. 14, 207-212.

19. Ryu, H. Y., S. M. Ahn, J. S. Kim, I. C. Jung, and H. Y. Sohn. 2010. Antimicrobial activity of fruit of Crataegus pinnatifide Bunge against multidrug resistant pathogenic Pseudomonas aeruginosa and Candida sp. Kor. J. Microbiol. Biotechnol. 38, 77-83.

20. Santos, F. A., E. M. A. Bastos, M. Uzeda, M. A. R. Carvalho, L. M. Farias, E. S. A. Moreira, and F. C. Braga. 2002. Antibacterial activity of Brazilian propolis and fractions against oral anaerobic bacteria. J. Ethnopharmacol. 80, 1-7.

21. Sohn, H. Y., Y. S. Kim, E. J. Kim, Y. S. Kwon, and K. H. Son. 2006. Screening of anti-acne activity of natural products 
against Propionibacterium acnes. Kor. J. Microbiol. Biotechnol. $34,265-272$.

22. Song, J. H. 2009. Current status and future strategies of antimicrobial resistance in Korea. Kor. J. Med 77, 143-151.

23. Yang, H. J., E. H. Kim, S. T. Kang, and S. N. Park. 2009. Antibacterial activity of Platycarya strobilacea extract and sta- bility of the extract-containing cream. Kor. J. Microbiol. Biotechnol. 37, 170-175.

24. Yu, Y. E., E. Y. Park, D. H. Jung, S. H. Byun, S. C. Kim, and S. M. Park. 2010. Development of antimicrobial dye for natural dyeing using natural substances. Kor. J. Microbiol. Biotechnol. 38, 32-39.

\section{초록 : 한약재 추출물의 피부 염증 유발 세균에 대한 항균활성}

유영은 ${ }^{1} \cdot$ 박은영 ${ }^{1}$ 정대화 ${ }^{1} \cdot$ 변성희 $^{2} \cdot$ 김상찬 ${ }^{12}$ - 박성민 ${ }^{1}{ }^{*}$

( ${ }^{1}$ 대구한의대학교 한방생명자원연구센터, ${ }^{2}$ 한의학과)

한약재 70종의 메탄올 추출물을 이용하여 4종의 Staphylococcus epidermidis와 S. aureus에 대한 항균효과를 조사 한 결과 모든 공시균주에 대하여 항균성을 나타내는 한약재는 황련, 소목, 오배자, 대황과 단삼으로 조사되었다. 이 중 우수한 항균성을 나타낸 오배자와 황련을 물, 에탄올, 메탄올과 에틸아세테이트를 추출 용매로 하여 추출물 을 제조하고 항균성을 조사한 결과 황련 열수 추출물에서 가장 우수한 항균성을 확인할 수 있었다. 황련의 항균 성은 berberine에 의한 것으로 가정하고 열수 추출물 중 berberine의 함량을 조사한 결과 $13.88 \%$ 로 조사되었다. Berberine에 의한 항균성과 다른 항생제와의 항균성을 비교하기 위하여 berberine chloride와 3 종의 항생제를 이 용하여 조사한 결과 $600 \mathrm{mg} / 1$ 이상의 berberine chloride 농도에서 KCCM 35494 S. epidermidis에 대한 항균성만 나타내었으며 다른 공시균주에 대한 항균성은 확인되지 않았다. 이에 본 연구에 사용한 공시균주에 대한 C.japonica 열수 추출물의 항균성은 고 농도의 berberine 또는 다른 물질에 의한 것으로 판단할 수 있었으며 이 물질에 대한 연구가 필요할 것으로 판단되었다. 